\title{
ANALGESIC ACTIVITY OF HYDROALCOHOLIC EXTRACT OF AERIAL PARTS OF MALVASTRUM COROMANDELIANUM
}

\author{
BHUPESH CS $^{1 *}$, ROHIT B ${ }^{2}$, KALYANI D ${ }^{2}$ \\ ${ }^{1}$ Department of Pharmacology, Institute of Pharmaceutical Research, GLA University, Mathura, Uttar Pradesh, India. ${ }^{2}$ Department of \\ Pharmacology, Acharya and B. M. Reddy College of Pharmacy, Bengaluru, Karnataka, India. Email: bhupesh115@gmail.com
}

Received: 13 May 2016, Revised and Accepted: 24 May 2016

\section{ABSTRACT}

Objective: The aim of this study is to explore the antinociceptive property of hydroalcoholic extract of Malvastrum coromandelianum. Pain is an unpleasant sensory and emotional experience associated with actual and potential tissue damage. Various types of pain are seen in humans, somatic, visceral, and neuropathic pain. M. coromandelianum belongs to Malvaceae family. Traditionally, it is used as an emollient, anti-inflammatory, analgesic, and antidysenteric.

Methods: The antinociceptive effects of hydroalcoholic extract of $M$. coromandelianum (HEMC) were evaluated by tail-flick, hot-plate, and acetic acid induced writhing method. Rats were divided into four groups. The first group which served as control was administered with aqueous $1 \%$ tragacanth suspension. The second group received standard drug, morphine ( $5 \mathrm{mg} / \mathrm{kg}$ ) orally as a suspension. Third and fourth group received HEMC ( 200 and $400 \mathrm{mg} / \mathrm{kg}$ ) and served as test drug treatment group, 30 minutes after treatment the reaction time and number of writhes was noted.

Results: HEMC produced significant antinociceptive effects against thermally induced pain. In tail-flick method, the peak effect of HEMC 400 mg/kg was shown at 60 minutes which is nearly equal to the peak effect of morphine $5 \mathrm{mg} / \mathrm{kg}$. In hot-plate method, the HEMC showed significant analgesic effect up to 3 hrs after the treatment, whereas morphine showed significant effect up to 6 hrs.

Conclusion: On the basis of finding, it may conclude that the HEMC shows its central analgesic action probably through inhibition of central pain receptors, whereas peripheral analgesic effect may be mediated by prostaglandin inhibition.

Keywords: Pain, Analgesia, Hydroalcoholic extract of Malvastrum coromandelianum, Morphine.

(C) 2016 The Authors. Published by Innovare Academic Sciences Pvt Ltd. This is an open access article under the CC BY license (http://creativecommons. org/licenses/by/4. 0/) DOI: http://dx.doi.org/10.22159/ajpcr.2016.v9i5.12822

\section{INTRODUCTION}

Pain is a warning signal that helps to protect the body from tissue damage [1]. Damaging stimuli activate and sensitize primary afferent nerve cells whose activity is to project the spinal cord to the brain, causing pain sensation [2]. Various pains are acute, chronic, somatic, visceral, cutaneous neuropathic pain, and phantom limb pain. Acute pain is defined as short-term but extreme pain that comes on quickly but last only for a brief period of time. It is a symptom that may be dealt with unhesitatingly and effectively with drugs, by injection if necessary, at the same time as the causative disease is addressed [3]. Chronic pain was originally defined as pain that has lasted 6 months or longer. It is now defined as pain that outlasts the precipitating tissue injury [4]. Somatic pain originates from ligaments, tendons, bones, blood vessels, and even nerves themselves. It is detected with somatic nociceptors. Visceral pain is poorly localized, diffuse and often in the midline, with the exception of joints and the mesentery [5]. Cutaneous pain is caused by injury to the skin or superficial tissues. Cutaneous nociceptors terminate just below the skin and due to the high concentration of nerve endings, produce a well-defined, localized pain of short duration [6]. Neuropathic pain or "neuralgia" can occur as a result of injury or disease to the nerve tissue itself. This can disrupt the ability of the sensory nerves to transmit correct information to the thalamus and hence the brain interprets painful stimuli even though there is no obvious or known physiologic cause for the pain [7]. Phantom limb pain is the sensation of pain from a limb that has been lost or from which a person no longer receives physical signals. It is an experience almost universally reported by amputees and quadriplegics [8].

Malvastrum coromandelianum is commonly known as false mallow, broom weed or clock plant [9]. It is a weed of waste places and plantations. It is found in waste ground, roadsides, in abandoned city, etc., [10]. The plant is considered to be emollient; leaves are applied to inflamed sores and wounds [11]. The essential oil from the leaves shows fungi toxicity against the damping-off fungi, Pythium aphanidermatum Fitzp (92.31\%), Pythium debaryanum Hesse (82.22\%), and Rhizoctonia solani Kuhn (72.22\%) [12]. The flowers are given as a pectoral and diaphoretic. It is used as antipyretic. It has smooth muscle relaxant property [13]. It is used as an anti-inflammatory, pectoral, diaphoretic, and antidysenteric agent [14].

\section{METHODS}

\section{Plant material}

Crude drug, i.e., aerial parts of $M$. coromandelianum was collected from the forest of Ghulewadi range and dried under shade. The crude drug was authenticated from Botanical Survey of India by PSN Rao, Joint Director of BSI, Pune. Then, the crude drug was dried and minced with a grinder into a powder and passed through sieve number 40 for the preparation of the extract.

\section{Preparation of the extract}

The powder was packed into a soxhlet apparatus and extracted with petroleum ether $\left(60-80^{\circ} \mathrm{C}\right)$ for $18 \mathrm{hrs}$. The same marc was successively extracted with chloroform and afterward with hydro-alcohol (30:70) for $18 \mathrm{hrs}$. The extracts were dried at $75^{\circ} \mathrm{C}$ in water bath for $5 \mathrm{hrs}$ when a solid mass was obtained in the case of hydroalcoholic extract, respectively, and were stored in airtight containers in the refrigerator at below $10^{\circ} \mathrm{C}$. The extracts thus obtained were subjected to phytochemical analysis for the various phytoconstituents.

\section{Phytochemical estimations of the extracts}

The preliminary phytochemical screening was carried out on the petroleum ether, chloroform, and ethanolic extract of aerial parts of M. coromandelianum for qualitative identification. Tests for common 
phytochemicals were carried out by standard methods described in practical pharmacognosy books $[15,16]$

\section{Experimental animals}

Albino rats (Wistar) weighing 150-200 g and mice 20-25 g of either sex were used in this study. The animals were acclimatized for 1 week under laboratory conditions. They were housed in polypropylene cages and maintained at $30^{\circ} \mathrm{C} \pm 2^{\circ} \mathrm{C}$ under $12 \mathrm{hrs}$ dark/light cycle. They were fed with standard diet and water ad libitum. The ethical clearance for handling the animals was obtained from the Institutional Animal Ethics Committee before the beginning of the project work.

\section{EXPERIMENTAL METHODS}

\section{Tail-flick method}

Fasted rats of either sex were divided into four groups $(n=6)$. Each rat served as its own control. Thus, before treatment, its reaction time was determined thrice at 0,20 and 40 minutes intervals. The mean of these three determinations constituted the "initial reaction time" - i.e., reaction time before treatment of the rat. The first group which served as control was administered with aqueous $1 \%$ tragacanth suspension. The second group received standard drug, morphine $(5 \mathrm{mg} / \mathrm{kg}$ ) orally as a suspension. The hydroalcoholic extract of $M$. coromandelianum (HEMC) was administered orally at $200 \mathrm{mg} / \mathrm{kg}$ to the third group and $400 \mathrm{mg} / \mathrm{kg}$ to the fourth group as suspension. Thirty minutes after treatment the reaction time was again evaluated at 30,60 , 90, 120, 150 and 180 minutes [17].

\section{Hot-plate method}

Fasted rats were divided into four groups $(n=6)$. Each rat served as its own control. Thus, before treatment, its reaction time was determined thrice at 0,20 and 40 minutes intervals. The mean of these three determinations constituted the "initial reaction time." The first group which served as control was administered with aqueous $1 \%$ tragacanth suspension. The second group received standard drug, morphine $(5 \mathrm{mg} / \mathrm{kg}$ intraperitoneal [IP]) as suspension. The HEMC was administered by IP route at $200 \mathrm{mg} / \mathrm{kg}$ to the third group and $400 \mathrm{mg} / \mathrm{kg}$ to the fourth group as suspension. Thirty minutes after treatment the reaction time was again evaluated at $0.5,1,2,3,6$ and 24 hrs [18].

\section{Acetic acid-induced writhing model}

In this model, animals were pretreated with drugs 30 minutes before induction of writhing. The Group I animals received vehicle and Group II animals received the reference standard indomethacin $(10 \mathrm{mg} / \mathrm{kg}$ p.o.). Analgesic activity of HEMC at doses 200 and $400 \mathrm{mg} / \mathrm{kg}$ p.o. (Groups III and IV) was accessed by counting the number of writhes induced by $0.7 \%$ acetic acid. The numbers of writhes per animal were counted for 20 minutes. Percent reduction in writhing syndrome was calculated and compared with the standard drug [19].

$$
\begin{gathered}
\text { Number of Writhes }[\text { Control }]- \\
\text { Inhibition }(\%)=\frac{\text { Number of Writhes }[\text { Treatment }]}{\text { Number of Writhes }[\text { Control }]} \times 100
\end{gathered}
$$

\section{RESULTS}

The preliminary phytochemical analysis like alkaloids, glycosides, carbohydrates, steroids, flavanoids, sponin, tannin, protein and amino acids was done with different extract of $M$. Coromandelianum according to standard procedure. The results of the preliminary phytochemical analysis of all the extracts were shown in Table 1.

Effect of analgesic activity of hydroalcoholic extract of M. Coromandelianum by tail-flick method

HEMC produced dose-dependent analgesic activity significantly $(p<0.01)$ against tail-flick method. The antinociceptive effects of the HEMC by the tail-flick test in rats are summarized in Table 2. Pretreatment with the extract significantly increased reaction time in comparison to control. At a dose of $400 \mathrm{mg} / \mathrm{kg}$ of HEMC exhibited analgesic effect to the same degree as morphine $5 \mathrm{mg} / \mathrm{kg}$ up to 150 minutes and at 180 minutes its effect was significant but lesser than the morphine $5 \mathrm{mg} / \mathrm{kg}$ in comparison with control. The peak effect of HEMC $400 \mathrm{mg} / \mathrm{kg}$ was shown at 60 minutes which is nearly equal to the peak effect of morphine $5 \mathrm{mg} / \mathrm{kg}$.

Effect of analgesic activity of hydroalcoholic extract of M. coromandelianum by Hot-plate method

The antinoceptive effect of HEMC by the hot-plate method was produced dose-dependently on mice and was showed in Table 3. At the dose of $200 \mathrm{mg} / \mathrm{kg}$, the effect was not significant after 30 minutes of its administration but its $400 \mathrm{mg} / \mathrm{kg}$ dose produced significant $(\mathrm{p}<0.01)$ effect. The HEMC showed peak effect at the dose of $200 \mathrm{mg} / \mathrm{kg}$ and $400 \mathrm{mg} / \mathrm{kg}$, respectively at 60 minutes after treatment while morphine was also showed peak effect at 60 minutes in comparison with control. Comparatively, the effect of high dose of HEMC was lesser than the effect of morphine. The HEMC showed significant analgesic effect up to $3 \mathrm{hrs}$ after the treatment whereas morphine showed significant effect up to $6 \mathrm{hrs}$.

Effect of analgesic activity of hydroalcoholic extract of $M$. coromandelianum by Acetic acid induced writhing effect

The HEMC produced significant $(\mathrm{p}<0.01)$ reduction in the number of writhing in mice in dose-dependent manner. At $200 \mathrm{mg} / \mathrm{kg}$ and $400 \mathrm{mg} / \mathrm{kg}$ oral dose, percent reduction of writhing was $92.14 \%$ and $95.17 \%$, respectively, as compared to control group, whereas the standard drug indomethacin $(10 \mathrm{mg} / \mathrm{kg}$ p.o.) showed a reduction of $86.45 \%$ as shown in Table 4 .

\section{DISCUSSION}

In indigenous system of medicine, several plants and herb have been used for the treatment of pain. M. coromandelianum is an herb which is used for the treatment of pain in various parts of Maharashtra district. Therefore, this study was an attempt to investigate the analgesic activity of $M$. coromandelianum. Preliminary phytochemical analysis showed that the HEMC revealed the presence of flavonoid, glycosides, saponin, triterpenes, and phenolic compounds. It is wellknown reported that flavonoid, triterpenoid saponins, and phenolic compounds possess analgesic and inflammatory activity [19]. From the study, it was observed that the in all the screening model of analgesic activity the HECM showed analgesic effect and M. coromandelianum has both peripheral and central analgesic properties. Its central analgesic

Table 1: Phytochemical analysis of different extracts of

\begin{tabular}{|c|c|c|c|c|}
\hline \multirow{2}{*}{$\begin{array}{l}\text { Pet ether } \\
\text { Carbohydrates }\end{array}$} & \multirow{2}{*}{$\begin{array}{c}\text { Chloroform } \\
\text { Molish's test }\end{array}$} & \multicolumn{3}{|c|}{ Hydro alcoholic } \\
\hline & & -ve & -ve & -ve \\
\hline & Benedict's test & -ve & -ve & -ve \\
\hline & Feeling's test & -ve & -ve & -ve \\
\hline \multirow[t]{4}{*}{ Alkaloids } & Mayer's test & -ve & -ve & -ve \\
\hline & Wagner's test & -ve & -ve & -ve \\
\hline & Dragendroff's test & -ve & -ve & -ve \\
\hline & Hager's test & -ve & -ve & -ve \\
\hline \multirow[t]{2}{*}{ Glycosides } & Modified borntragger's test & -ve & $+\mathrm{ve}$ & +ve \\
\hline & Legal's test & -ve & +ve & +ve \\
\hline Saponins & Froth test & + ve & +ve & +ve \\
\hline \multirow{2}{*}{$\begin{array}{l}\text { Phytosterols and } \\
\text { triterpenoids }\end{array}$} & Liberman burchard test & $+\mathrm{ve}$ & + ve & $+v e$ \\
\hline & Salkowski's test (steroid) & +ve & +ve & +ve \\
\hline Fats and oil & Stain test & +ve & +ve & +ve \\
\hline \multirow{2}{*}{$\begin{array}{l}\text { Phenolic and } \\
\text { tannins }\end{array}$} & Ferric chloride test & $-\mathrm{ve}$ & -ve & $+v e$ \\
\hline & Lead acetate test & -ve & -ve & $+\mathrm{ve}$ \\
\hline Test for flavonoids & Shinoda test & -ve & -ve & +ve \\
\hline \multirow{3}{*}{$\begin{array}{l}\text { Proteins and } \\
\text { amino acids }\end{array}$} & Milon's test & -ve & -ve & -ve \\
\hline & Biuret test & -ve & -ve & -ve \\
\hline & Ninhydrin test & -ve & -ve & -ve \\
\hline
\end{tabular}
M. coromandelianum 
Table 2: Effect of analgesic activity of hydroalcoholic extract of $M$. Coromandelianum by tail-flick method

\begin{tabular}{|c|c|c|c|c|c|c|}
\hline \multirow[t]{3}{*}{ Treatment } & \multicolumn{6}{|c|}{ Increase in reaction time (sec) } \\
\hline & \multicolumn{6}{|c|}{ Different time interval (minute) } \\
\hline & 30 & 60 & 90 & 120 & 150 & 180 \\
\hline Control & $-1.090 \pm 0.51$ & $-0.412 \pm 0.55$ & $0.178 \pm 0.86$ & $0.060 \pm 0.73$ & $0.060 \pm 0.73$ & $-0.78 \pm 0.48$ \\
\hline Morphine (5mg/kg) & $6.146 \pm 0.58^{* *}$ & $7.379 \pm 0.34^{* *}$ & $3.829 \pm 0.45^{* *}$ & $3.476 \pm 0.18^{* *}$ & $2.651 \pm 0.27^{* *}$ & $1.064 \pm 0.24^{* *}$ \\
\hline HEMC (200mg/kg) & $4.282 \pm 0.82 * *$ & $5.112 \pm 0.71^{* *}$ & $3.312 \pm 0.70^{* *}$ & $3.095 \pm 0.44^{* *}$ & $1.828 \pm 0.49^{* *}$ & $0.650 \pm 0.41^{*}$ \\
\hline HEMC (400mg/kg) & $4.690 \pm 0.70 * *$ & $5.745 \pm 0.68 * *$ & $3.453 \pm 0.51^{* *}$ & $3.288 \pm 0.79 * *$ & $1.998 \pm 0.40^{* *}$ & $0.710 \pm 0.28^{*}$ \\
\hline
\end{tabular}

${ }^{* *} \mathrm{p}<0.01$ : Very significant, ${ }^{*} \mathrm{p}<0.05$ : Significant, Number of animals $\mathrm{n}=6$, values are expressed as mean \pm SEM, SEM: Standard error of mean,

M. coromandelianum: Malvastrum coromandelianum, HEMC: Hydroalcoholic extract of M. coromandelianum

Table 3: Effect of analgesic activity of hydroalcoholic extract of $M$. coromandelianum by Hot-plate method

\begin{tabular}{|c|c|c|c|c|c|c|}
\hline \multirow[t]{3}{*}{ Treatment } & \multicolumn{6}{|c|}{ Increase in reaction time (sec) } \\
\hline & \multicolumn{6}{|c|}{ Different time interval (h) } \\
\hline & 0.5 & 1 & 2 & 3 & 6 & 24 \\
\hline Control & $0.623 \pm 0.07$ & $0.704 \pm 0.15$ & $0.266 \pm 0.16$ & $0.498 \pm 0.17$ & $0.503 \pm 0.13$ & $0.4842 \pm 0.19$ \\
\hline Morphine (5 mg/kg) & $5.493 \pm 0.73^{* *}$ & $9.476 \pm 0.50 * *$ & $6.976 \pm 0.64^{* *}$ & $5.241 \pm 0.5^{* *}$ & $2.491 \pm 0.45^{* *}$ & $0.7242 \pm 0.19 \mathrm{~ns}$ \\
\hline HEMC (200 mg/kg) & $2.415 \pm 0.58 \mathrm{~ns}$ & $3.177 \pm 0.49 * *$ & $2.618 \pm 0.37 * *$ & $1.808 \pm 0.24^{*}$ & $0.493 \pm 0.07 \mathrm{~ns}$ & $0.2700 \pm 0.06 \mathrm{~ns}$ \\
\hline HEMC (400 mg/kg) & $5.281 \pm 1.19^{* *}$ & $5.281 \pm 1.19^{* *}$ & $5.281 \pm 1.19 * *$ & $2.729 \pm 0.16^{* *}$ & $1.083 \pm 0.20 \mathrm{~ns}$ & $0.6608 \pm 0.31 \mathrm{~ns}$ \\
\hline
\end{tabular}

${ }^{* *} \mathrm{p}<0.01$ : Very significant, ${ }^{*} \mathrm{p}<0.05$ : Significant, Not significant: $\mathrm{p}>0.05$, Number of animals $\mathrm{n}=6$, values are expressed as mean \pm SEM, SEM: Standard error of mean,

M. coromandelianum: Malvastrum coromandelianum, HEMC: Hydroalcoholic extract of M. coromandelianum

Table 4: Effect of analgesic activity of hydroalcoholic extract of M. coromandelianum by acetic acid induced writhing effect

\begin{tabular}{lll}
\hline Treatment & $\begin{array}{l}\text { Number of } \\
\text { writhing }\end{array}$ & $\begin{array}{l}\text { Percentage } \\
\text { reduction }\end{array}$ \\
\hline Control & $77 \pm 1.67$ & 0.0 \\
Indomethacin $(10 \mathrm{mg} / \mathrm{kg})$ & $8.33 \pm 0.63^{*}$ & 86.45 \\
HEMC $(200 \mathrm{mg} / \mathrm{kg})$ & $4.83 \pm 0.47^{*}$ & 92.14 \\
HEMC $(400 \mathrm{mg} / \mathrm{kg})$ & $2.67 \pm 0.25^{*}$ & 95.17 \\
\hline
\end{tabular}

${ }^{*} \mathrm{p}<0.01$ : Very significant, Number of animals $\mathrm{n}=6$, values are expressed as mean \pm SEM, SEM: Standard error of mean, M. coromandelianum: Malvastrum coromandelianum, HEMC: Hydroalcoholic extract of M. coromandelianum

activity was confirmed through tail-flick and hot-plate method and its peripheral analgesic property was confirmed by writhing test. Effect of HEMC on tail-flick response provides a confirmation of its central effect since the tail-flick is predominantly a spinal reflex and is considered to be selective for centrally acting analgesic compounds such as morphine, pethidine, while peripheral analgesic is known to be inactive on this kind of painful stimulus $[20,21]$. Nociceptive pathways activated in the tail-flick and hot-plate tests are not the same $[22,23]$. Therefore, in different antinociceptive tests the same opioid ligand can elicit different responses, even though the same receptors are involved. This is also supported by our results since the extent of analgesic activity exhibited by tail-flick method is greater than the hot-plate method. Its peripheral analgesic activity was confirmed from its inhibitory effects on chemical (acetic acid) induced nociceptive stimuli. The IP injection of acetic acid increase the mediators of pain especially prostaglandin E2 and prostaglandin $2 \alpha$ which elicited writhings $[24,25]$ (a syndrome characterized by a wave of abdominal musculature contraction followed by extension of the hind limbs). Moreover, acetic acid also increases the vascular cell permeability, mast cell degranulation, and smooth muscle contraction. Eosinophils and chemotaxis stimulate the nociceptor and produce pain response. Peripheral analgesic effect of plant's extract may be mediated by prostaglandin inhibition, whereas the central analgesic action of the extract probably mediated through inhibition of central pain receptors. Analgesic effect of extract exhibited after 30 minutes of its administration. Analgesic effect of extract last after 3 hrs and shows a maximum antinociceptive effect after $1 \mathrm{hrs}$ its administration. Both the doses showed analgesic effect. The dosedependent inhibition of writhings induced by acetic acid in this study by $M$. coromandelianum suggests a peripherally mediated analgesic activity based on the association of the model with stimulation of peripheral receptors, especially the local peritoneal receptors at the surface of cells lining the peritoneal cavity. This suggests that chemical constituents by the virtue of them showed pharmacological action has a rapid onset of action and of the short duration of action.

\section{CONCLUSION}

The analgesic activity of $M$. coromandelianum was conducted, and a significant activity was found. Hence, it can be used to develop analgesic medications.

\section{REFERENCES}

1. Seattle WA. Classification of Chronic Pain: Descriptions of Chronic Pain Syndromes and Definitions of Pain Terms. Seattle: IASP Press; 1994.

2. Fields HL, Levine JD. Pain - mechanics and management. West J Med 1984;141(3):347-57.

3. Benett PN, Brown MJ. Clinical Pharmacology. $9^{\text {th }}$ ed., Vol. 3. London: Churchill Livingstone; 2003. p. 19-22.

4. Rang HP, Dale MM, Ritter JM, Moore PR. Pharmacology. $6^{\text {th }}$ ed. Edinburg: Elsevier; 2007. p. 589.

5. Serpell M. Anatomy, physiology and pharmacology of pain. Surgery (Oxford) 2006;24(10):350-3.

6. Strigo IA, Duncan GH, Boivin M, Bushnell MC. Differentiation of visceral and cutaneous pain in the human brain. J Neurophysiol 2003;89(6):3294-303.

7. Meyerson BA, Linderoth B. Mode of action of spinal cord stimulation in neuropathic pain. J Pain Symptom Manage 2006;31 4 Suppl: S6-12.

8. Almeida SM, Almeida MR. Dictionary of Generic Names of Flowering Plants and Ferns in Maharashtra. Mumbai: Orient Press Ltd.; 2005. p. 202.

9. Chopra RN, Nayar SL, Chopra IC. Glossary of Indian Medicinal Plants. $7^{\text {th }}$ ed. New Delhi: National Institute of Science Communication and Information Resources; 2006. p. 161.

10. The wealth of India. A Dictionary of Indian Raw Materials and Industrial Products. $1^{\text {st }}$ ed. New Delhi: National Institute of Science Communication and Information Resources; 2003. p. 89.

11. Dahanukar SA, Kulkarni RA, Rege NN. Pharmacology of medicinal plants and natural products. Ind J Pharmacol 2000;32(4):81-118.

12. Khare CP. Indian Medicinal Plants: An Illustrated Dictionary. $1^{\text {st }}$ ed. New Delhi: Springer Private Limited; 2007. p. 396.

13. Kokate CK. Practical Pharmacognosy. $3^{\text {rd }}$ ed. New Delhi: Vallabh 
Prakashan; 1991.p. 107-11.

14. Khandelwal KR. Practical Pharmacognosy. $10^{\text {th }}$ ed. New Delhi: Nirali Prakashan; 2003. p. 149.

15. Marinho BG, Miranda LS, Gomes NM, Matheus ME, Leitão SG, Vasconcellos ML, et al. Antinociceptive action of (/-)-cis-(6ethyl-tetrahydropyran-2-yl)-formic acid in mice. Eur $\mathrm{J}$ Pharmacol 2006;550(1-3):47-53.

16. Ojewole JA. Antinociceptive, anti-inflammatory and antidiabetic properties of Hypoxis hemerocallidea Fisch. \& C.A. Mey. (Hypoxidaceae) corm ['African Potato'] aqueous extract in mice and rats. J Ethnopharmacol 2006;103(1):126-34.

17. Reddy YS, Sama V, Suresh B. Antinociceptive activity of Malvastrum Coromandelianum. Fitoterapia 2001;72(3):278-80.

18. Ramabadran K, Bansinath M, Turndorf H, Puig MM. Tail immersion test for the evaluation of a nociceptive reaction in mice. Methodological considerations. J Pharmacol Methods 1989;21(1):21-31.

19. Krasteva I, Platikanov S, Nikolov S, Kaloga M. Flavonoids from
Astragalus hamosus. Nat Prod Res 2007;21(5):392-5.

20. Ramabadran K, Bansinath M, Turndorf H, Puig MM. Tail immersion test for the evaluation of a nociceptive reaction in mice. Methodological considerations J Pharm Methods 1989;21:21-31.

21. Srinivasan K, Muruganandan S, Lal J, Chandra S, Tandan SK, Raviprakash V, et al. Antinociceptive and antipyretic activities of Pongamia pinnata leaves. Phytother Res 2003;17(3):259-64.

22. Bodnar RJ, Hadjimarkou MM. Endogenous opiates and behavior: 2001. Peptides 2002;23(12):2307-65.

23. Schaible HG, Richter F. Pathophysiology of pain. Langenbecks Arch Surg 2004;389(4):237-43.

24. Deraedt R, Jouquey S, Delevallée F, Flahaut M. Release of prostaglandins $\mathrm{E}$ and $\mathrm{F}$ in an algogenic reaction and its inhibition. Eur J Pharmacol 1980;61(1):17-24.

25. Duarte ID, Nakamura M, Ferreira SH. Participation of the sympathetic system in acetic acid-induced writhing in mice. Braz J Med Biol Res 1988;21(2):341-3 